doi:10.18575/msrs.sm.e.17.11
UDC 612.018:543.3

COBISS.RS-ID 6401560

\title{
Chemism and the Role of Endocannabinoids in Physiological Processes
}

\begin{abstract}
Despite being known for 5000 years, after the records of imperial Chinese doctors, cannabinoids as a subject of scientific research experienced its rise after 1964, when delta nine tetrahydrocannabinol $(\triangle 9 \mathrm{THC})$ by Israeli scientists was identified. This was followed by the discovery of endogenous ligand / endocannabinoids, as well as receptors CB1 and CB2.

In a broader sense, endocannabinoids act as neuromodulators and immunomodulators. They are included in the various physiological processes such as: the occurrence of pain, cognition, memory formation and neuroplasticity, physical activity, respiratory processes, appetite regulation, control and heart rate, nausea and emesis, intraocular pressure, inflammatory and immune processes (antigen recognition).
\end{abstract}

Key Words: Endocannabinoids, anadamide, cannabinoid receptors.

(Scr Med 2017:48:77-81)
Ranka Prerad, Božo Krivokuća ${ }^{2}$, Aleksandar Jakovljević ${ }^{2}$, Ostoja Savić́, Dušan Janičić ${ }^{2}$

${ }^{1}$ University of Travnik, Faculty of Pharmacy, Travnik

${ }^{2}$ The University Clinical Centre of the Republic of Srpska, Faculty of Medicine, Banja Luka

\section{Contact address:}

Božo Krivokuća

The University Clinical Centre of the Republic of Srpska, Faculty of Medicine, Banja Luka

$780 o o$ Banja Luka, Republic of Srpska

Bosna and Herzegovina e-mail:bozokrivokuca @gmail.com phone number: +387-65-516-859

Submitted: October $22^{\text {nd }}, 2016$ Accepted: November $22^{\text {nd }}, 2016$

\section{Introduction}

Endocannabinoids were named after a plant cannabis or fitocannabinoids. Studying fitocannabinoids has resulted in the development of the most important physiological endocannabinoid system (ECS) that is important for the establishment and maintaining homeostasis in humans.

In 1964, dr. Raphael Mechoulam, dr. Lumir Ondrej Hanus and their followers at the Hebrew University in Jerusalem identified $\Delta$ (delta) -9-tetrahydrocannabinol (THC) in cannabis. The following research led to the development of a receptor on which THC is connected as well as the development of endocannabinoid and endocannabioid system.

Endocannabinoids are endogen agonist/ligand of cannabinoid receptors $\mathrm{CB}_{1}$ and $\mathrm{CB}_{2}$ which are produced in mammalian tissues.

The first endogen cannabinoid anandamid (arahidoniletanolamid or AEA) was isolated and described by Czech chemist Ondrej Lumir Hanus and American molecular pharmacologist William Anthony Dekane in 1992.The name itself was given according to the Sanskrit word ananda which means blissfulness. ${ }^{2}$ Shortly after the discovery of the first one, the other endogenous cannabinoid, 2-arahidonilglicerol (2-AG), was developedby Shimona Ben-Shabat, one of the first students of the above mentioned doctors.

Picture 1. Anandamide (AEA) (3).

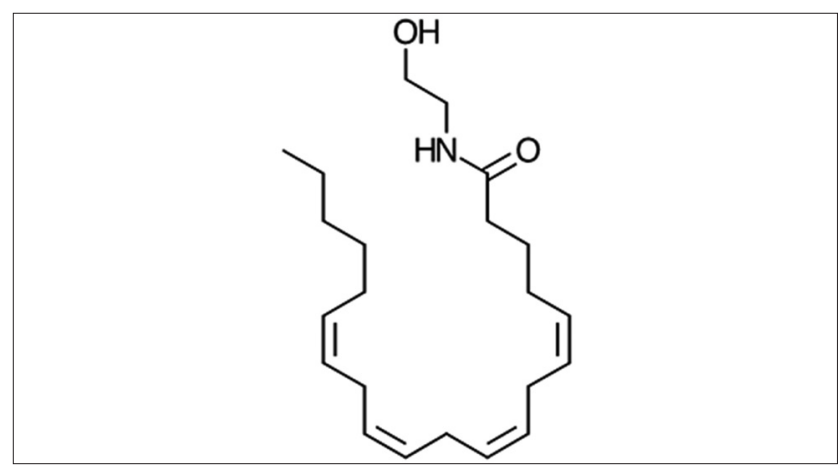


Picture 2. 2-arachidonyl-glycerol(2-AG) (4).

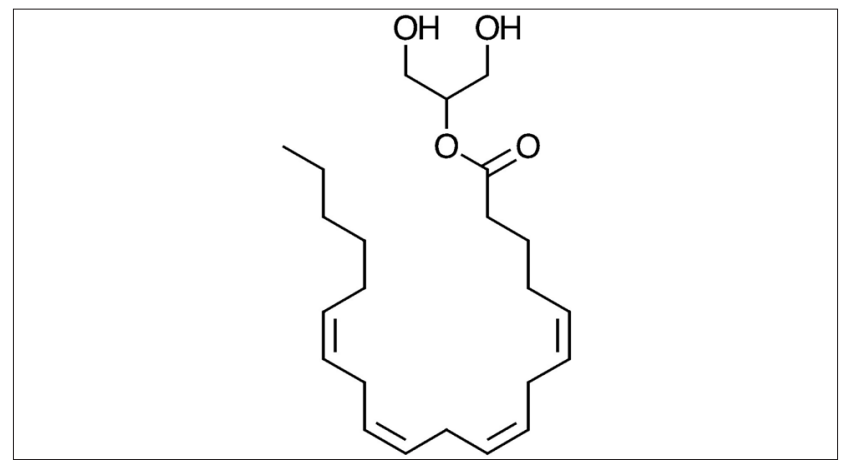

Endocannabinoids are derived from arachidonic acid and they can be amids, ester or eter with long unsaturated fat acids. According to their own chemism, they are hydrophobic molecules and hence they do not migrate through the body so their engagement is local, surrounded by the space that is close to synthesis molecules endocannabinoids. ${ }^{3-6}$

The most examined endocannabinoids ( Picture 1 and 2) are arachidonyletanolamid (anandamide, AEA) and 2- arachidonyl-glycerol (2-AG). The theory, accoridng to which their synthesis appears when neccessary, was refuted and it was proved that anandamide was and is contained in some cells. The other representatives of endocannabinoid are: 2-arachidonyl-glycerol (noladin), O- arachidonyletanolamin (virodhamine), $\mathrm{N}$-arachidonyldopamine and others.

Synthesis of anandomide is carried out parallely in a few different ways upon which are contained different enzymes (phospholipase D, phospholipase $\mathrm{C}, \alpha, \beta$, hydrolase 4 and different phospholipases). Precursor for the synthesis of anandamide is a membrane phospholipid $\mathrm{N}$ - arachidonyle phosphatidyl- ethanolamine. ${ }^{6}$

Synthesis of anandomide in neuron is stimulated by a binding of a neurotransmitter that is released from presynaptic neuron in an adequate inotrope or metabotropic receptor on postsynaptic neuron.

This process causes increased cytosolic free calcium-ions concentration in postsynaptic neuron which represents a stimulant for synthesis and releasing endocannabinoids from their precursors in a membrane. The released endocannabinoids are bound to receptors $\mathrm{CB} 1$ on presynaptic membrane. After that, activated receptors inhibitate potassium canals that are dependent on power.

Due to the increased diffusion of potassium ions, depolarization of presynaptic membrane is decreased. The consequence is the inhibition of neurotransmitters release such as glutamate, dopamine and $\gamma$ - aminobutyric acid (GABA). ${ }^{7,8}$

Termination of biological results of anandamide is carried out in two parts. In the first part, anandamide migrates into the cell, while in the second part, it is decomposed with the help of hydrolase amid fatty acid FAAH (Fatty Acide Amide-Hydrolase). ${ }^{9}$ Bearing in mind that anandamide is a lipofiln molecule, it can migrate into the cell via passive diffusion in the direction of concentrated gradient. The transport anandamide in the cell is also enabled via selective transport molecule called AMT (anandamide membrane transporter), which is placed in the membrane plasma and acts reversible. There are two other known mechanisms by which it is possible to endorse anandamide in the cell, that is, with intracellular membrane vesiculum and with the help of endocytosis. $^{10-14}$

Using transgenic animal models, without genes for receptors $\mathrm{CB}_{1}$ and $\mathrm{CB}_{2}$, other receptors on which endocannabinoid is carried out were gradually developed. Receptors TRVP (transient receptor potential cation channel subfamily $\mathrm{V}$ member vaniloid receptor) participate in the regulation of body temperature and system of nocicepsys that medites signals to pain stimuli. Receptors GPR55 (protei-coupled receptor) has 13\% of homology with receptors CB1 and $14 \%$ of homology with receptor $\mathrm{CB} 2$. It is placed in the brain, liver, spleen, intestines, fetal tissues and placenta. It is a very serious candidate to be named receptor $\mathrm{CB} 1 .{ }^{15,16}$

\section{The role of endocannabinoid in physiological processes}

In wide range, endocannabinoids work as a neuromodulator and immunomodulator. They are included in different physiological processes such as: pain, cognitive processes, memory formation and neuroplasticity, motoric activities, endocrine processes, regulation appetite, control and puls, nausea, intraocular pressure, inflammatory and immune processes (antigen). ${ }^{17,18}$

Endocannabinoids are intracellular transmitters (vectors) of signals close to the neurons in synapsis. Since they are lipophilic molecules, they are not contained in intracellular vasculum but after synthesis, they become a part of cellular membrane. It is characteristic for them to participate in retrograde signalling between neurons, which means that the signal, instead from presynaptic neuron, travels to postsynaptic neuron in another way (Picture 3). Endocannabinoids are released in the synaptic cut from the postsynaptic neuron and act on presynaptic nerve endings. Activation of cannabinoid receptors 
on presynaptic neuron for the small amount of time inhibitates the release of the second neurotransmitter. The final result is dependent on the type of neuron which is inhibitated from cannabinoid such as, for example, inhibition of excitatory neurotransmitters such as glutamate leads to inhibition of an excilatory neuron, while inhibition of releasing inhibitive neurotransmitter GABA (gamma-aminobutyric acid) leads to the increasment of excitability. ${ }^{19}$

Picture 3. Schematic diagram of endocannabinoid activity in presinapse and retrogressive modulation of releasing neurotransmitters glutamate and GABA (gammaamino fatty acid), AEA (arachidonyletanolamid), 2-AG (2arachidonyl-glycerol) (20).

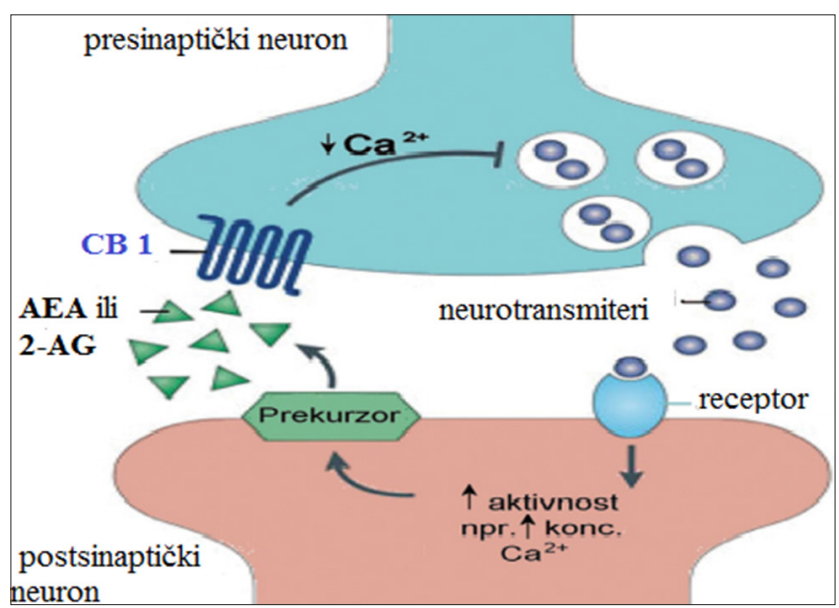

\section{Endogenous cannabinoid receptors}

The first proof of the presence of cannabinoid receptors was the evidence that THC inhibitates adenyl cyclase, after which studies that used radioligandi followed.19,20 The first cannabinoid receptor CB1 was cloned in 1990 from the cell of a mouse brain, while the other cannabinoid receptor CB2 was cloned in 1993 from human cells of promyelocytic leukemia HL-60. ${ }^{21,22}$

Cannabinoid receptors are divided in two types - $\mathrm{CB}_{1}$ and $\mathrm{CB} 2$. They are rated as high affinity 7 -transmembrane receptors that are connected with $\mathrm{G}$ protein. Activation of receptors causes the induction of different intracellular processes: inhibition of adenyl cyclase and, as a consequence, concentration of CAMP decreases (adeonid cyclic $5^{-}$monophosphate), activation with mitogen- activated protein kinase ERK (extracellular signal-regulated kinase), amino terminal kinase, activation of phosphatidylinositol 3-kinase, degradation of sphingomyelin, as well as the ceramide occurence. ${ }^{23-25}$

Receptors $\mathrm{CB}_{1}$ and $\mathrm{CB}_{2}$ have just $44 \%$ conguence with the chain amino acids while in the domen of binding, they have more similarity in sequences of amino acids (68\%), which is the reason why some ligands do not make difference in binding to $\mathrm{CB}_{1}$ or $\mathrm{CB}_{2}$ receptors. It is interesting that human receptors $\mathrm{CB}_{1}$ have high similarity to other animal types ( monkeys 100\%, rats 97\%, mice 96\%). ${ }^{26}$

\section{Receptors CB $_{1}$}

Receptors $\mathrm{CB}_{1}$ are present in the central nervous system as well as in the periphery tissues. In the brain, they are in the parts that control motor activities (basal ganglia and cerebellum), memory and cognitive functions (cortex and hypocampus), emotions (amigdala), sensory perceptions (thalamus), autonomy and endocrine functions (hypothalamus, pons and medul). Distribution of $\mathrm{CB}_{1}$ receptors in the brain is in accordance with famous pharmacodinamic results regarding the effects of cannabinoid on memory, cognitive activities, pain and movement. Low concentration of receptors $\mathrm{CB}_{1}$ is present in a brainstem, extended spinal cord and tilamus. The above mentioned explains why cannabinoids do not cause mortality due to dangerous acts on vital physiological functions in cases of ingestion of a very high dose of cannabinoid. According to the data published in American Scientist in December 2015, mortality assosiated with the use of cannabis in the USA was around o, as well as in 2014 and, in contrast to alcohol, which caused 30700 deaths in 2015. ${ }^{27}$ On the periphery, they are located in testicles, vascular endothelium, spleen and periphery nerves. ${ }^{1,21,23,28}$

\section{Receptors $\mathrm{CB}_{2}$}

In comparison with $\mathrm{CB}_{1}$ receptors, $\mathrm{CB}_{2}$ receptors are primarily manifested in the cells of the immune system and they participate in modulation of functional ascpect of the immune system. The large number of receptors $\mathrm{CB}_{2}$ is expressed in lymphocytes $\mathrm{B}$ and in natural cells killers (natural killers NK). Aditionallly, they are present in tonsils, spleen and in lymph nodes. Some cannabinoids act on validus receptors and T-type calcium channels. It is generally considered that psychoactive cannabinoid results are dispatched through $\mathrm{CB}_{1}$ receptors, while immunomodular ones are dispatched through $\mathrm{CB}_{2}$ receptors. ${ }^{21,28-30}$

\section{Conclusion}

The oldest records regarding the medical use of cannabis are known since the time of Chinese imperial herbalist Shen Nung 5000 years ago, who recommended cannabis for curing malaria, beriberi, constipation, rheumatological pains, shortage of concentration and woman problems. The famous doctor of that time in China, Hua Tuo, used the mixture of cannabis resin and 
wine as analgesic in cases of surgery. Medical use of cannabis is also well known in all old civilizations such as India, Mesopotamia and Ancient Egypt. ${ }^{30,31}$

Although cannabinoids have been used for centuries, the range of studies that examines the consequences of cannabinoid has developed in the last 50 years, after the development of cannabinoid receptors and their endogen ligand. The research is not only conducted in the field of basic mechanism of cannabinoid activity but in the developing pharmacological and therapeutic results of cannabinoid. Until now, there are more than 150000 studies connected to the theme of endocannabinoid systems, endocannabinoid as well as pharmacological and therapeutic activity of phytocannabinoid. The fact that more and more countries all over the world legalize the use of medical cannabis speaks in favor of justification of clinical studies carried out with the usage of cannabinoid, as well as the validity of positive results that are obtained by these studies.

\section{References}

1. Hanus ${ }^{\vee}$ L.O,Mechoulam R.: Cannabinoid chemistry: an overview. Department of Medicinal Chemistry and Natural Products, Medical Faculty, The Hebrew University of Jerusalem, Ein Kerem Campus, 91120 Jerusalem, Israel, 2005 .

2. 2. Devane WA, Hanus L, Breuer A, Pertwee RG, Stevenson LA, Griffin G, Gibson D, Mandelbaum A, Etinger A, Mechoulam R Isolation and structure of a brain constituent that binds to the cannabinoid receptor". Science, 1992; 258 (5090): 1946-9.

https://doi.org/10.1126/science.1470919

3. Picture 1: Anandamid (AEA). Available on: https:// hu.wikipedia.org/wiki/Anandamid (25.6.2016).

4. Picture 2: 2-arahidonilglicerol(2-AG). Available on: https://sr.wikipedia.org/wiki/2-Arahidonoilglicerol (25.6.2016).

5. Fonseca BM, Costa MA, Almada M, Correia-da--Silva G, Teixeira NA. Endogenous cannabinoids revisited: a biochemistry perspective. Prostaglandins \& other lipid mediators. 2013; 102-103: 13-30.

https://doi.org/10.1016/j.prostaglandins.2013.02.002 PMid:23474290

6. Alger BE, Kim J.: Supply and demand for endocannabinoids. Trends in neurosciences. 2011; 34(6):304315 https://doi.org/10.1016/j.tins.2011.03.003 PMid:21507493 PMCid:PMC3106144

7. Guzman M Cannabinoids: potencial anticancer agens. Nat. Rev Cancer 2003; 3(10): 745-755. https://doi.org/10.1038/nrc1188 PMid:14570037

8. Lopez Rodriguez ML, Viso A, Ortega A, Gutierrez S, az al. Design synthesis and biological evaluation of new endocannabinoid transporter inhibitor. Eur J Med Chem 2003; 38(4): 403-412. https://doi.org/10.1016/So223-5234(03)ooo45-X

9. Liu J, Wang L, Harvey-White $J$, et al. Multiple Pathways Involved in the Biosytheses of Anandamide. Neuropharmacology, 2008; 54(1): 1-7. https://doi.org/10.1016/j.neuropharm.2007.05.020 PMid:17631919 PMCid:PMC2219543

10. Deutsch DG Glaser ST, Howell JM et al. The cellular uptake of anandamide is coupled to its brakedown by fatty acide amide hydrolase. J Biol Chem 2001; 276(10): 6967- 6973. https://doi.org/10.1074/jbc.Moo3161200 PMid:11118429

11. Giuffrida A, Beltramo M, Poimelli D Mehanisms of endocannabionoid inactivation: byochemistry and pharmalogicy. J Pharmacol Exp Ther 2001; 298(1): 7-14. PMid:11408519

12. Maccarrone $\mathrm{M}$, Bari $\mathrm{M}$, Battista $\mathrm{N}$ et al. Endocannabinoid degradation, endotoxic shock and inflammation. Curr Drug Targets Inflamm Allergy 2002; 1(1) 53-63.

https://doi.org/10.2174/1568010023344878 PMid:14561206

13. Bisogno T, MacCarrone M, De Petrocellis L et al. The uptake by cell of 2- arachidonoylglycerol an endogenous agonist of cannabinoid receptors. Eur J Biochem 2001; 268(7): 1982-1989.

https://doi.org/10.1046/j.1432-1327.2001.02072.x PMid:11277920

14. MacCarrone M, Finazzi-Agro A. Anandamide hydrolase: a guardian angel of human reproduction? Trends Pharmacol Sci 2004; 25(7):353-7.

https://doi.org/10.1016/j.tips.2004.05.002 PMid:15219977

15. Ryberg E, Larsson N, Sjogeren S,at al. The orphan receptor GPR55 is a novel cannabinoid receptor. British journal of pharmacology. 2007; 152(7): 1092- 1101. https://doi.org/10.1038/sj.bjp.0707460 PMid:17876302 PMCid:PMC2095107

16. Moriconi A, Cerbara I, Maccarrone M, Topai A, GPR55 : Current knowledge and future perspectives of purported » Type 3 » cannabinoid receptor. Current medicinal chemistry, 2010; 17(14):1411-1429 https://doi.org/10.2174/092986710790980069

17. Fine PG, Rosenfeld MJ. The endocannabinoid system, cannabinoids, and pain. Rambam Maimonides medical journal. 2013; 4(4):eoo22. https://doi.org/10.5041/RMMJ.10129 PMid:24228165 PMCid:PMC3820295

18. Zogopoulos P, Vasileiou I, Patsouris E, Theocharis SE. The role of endocannabinoids in pain modulation. Fundamental \& clinical pharmacology. 2013; 27(1): 64-80. https://doi.org/10.1111/fcp.12008 PMid:23278562

19. Freund TF, Katona I, Piomelli D. Role of endogenous cannabinoids in synaptic signaling. Physiological reviews. 
2003; 83(3): 1017-10.

https://doi.org/10.1152/physrev.00004.2003 PMid:12843414

20. Picture 3: Schematic diagram of endocannabinoid activity in presinapse and retrogressive modulation of releasing neurotransmitters glutamate and GABA (gamaamino fatty acid), AEA (arahidoniletanolamid), 2-AG (2-arahidonilgliceril). Available on: http://www.nijz.si/ sites/www.nijz.si/files/uploaded/ferjan_in_sod_zv_2015. $\operatorname{pdf}(27.6 . .2016)$.

21. Szabo Bela: Pharmacology of Cannabinoids Receptors. BT Review 2008; 2(2).

22. Guzman M Cannabinoids: Potencial anticancer agens. Nat. Rev Cancer 2003; 3(10): 745-755. https://doi.org/10.1038/nrc1188 PMid:14570037

23. Howlett AC, Barth F, Bonner Ti et al. International Union of Pharmacology XXVII. Classification of cannabinoid receptors. 2002; 54(2): 161-202.

24. Melck D, Rueda D, Galve-Roperth et al.Involvment cAMP protein kinase A pattway and mitogen activated protein kinase in the antiproliferative effects of anandamide in human breast cancer cells. FEBS Lett 1999; 463(3): 235240.

https://doi.org/10.1016/Soo14-5793(99)01639-7
25. McPartland JM, Glas M Funcional mapping of cannabinoid receptor homologs in mammals other vertebrates and invertebrates. Gene. 2003; 312: 297-303. https://doi.org/10.1016/So378-1119(03)00638-3

26. Maurice R. Elphick, Egertova M.; The neurobiology and evolution of cannabinoid signalling. 2001. https://doi.org/10.1098/rstb.2000.0787

27. Available on : post https://www.washingtonpost.com/ news/wonk/wp/2015/12/22/americans-are-drinkingthemselves-to-death-atrecord-rates/ (8.9.2016).

28. Pertwee RG. Pharmacology of cannabinoids CB1 in $\mathrm{CB}_{2}$ receptors.Pharmacol Ther 1997; 74(2): 129-180. https://doi.org/10.1016/So163-7258(96)oo204-5 https://doi.org/10.1016/So163-7258(97)82001-3

29. Howlett AC, Breivogel CS, Childers SR et al Cannabinoid physiology and pharmacology: 30 years of progress. Nevropharmacology. 2004; 47 Suppl 1: 345-358. https://doi.org/10.1016/j.neuropharm.2004.07.030 PMid:15464149

30. Li Hui-Lin : "The Origin and Use of Cannabis in Eastern Asia: Linguistic-Cultural Implications”. Economic Botany. Springer, New York 1973; 293-301.

31. Abel Ernest: Marijuana, The First 12,000 years. Plenum Press, New York, 1980.

\section{Hemizam i uloga endokanabinoida u fiziološkim procesima}

\section{SAŽETAK}

lako poznati već 5000 godina po zapisima carskih kineskih ljekara, kanabinoidi kao predmet naučnih istraživanja doživljavaju svoj uspon nakon 1964. godine kada je od strane izraelskih naučnika identifikovan delta devet tetrahidrokanabinol ( $\triangle 9 \mathrm{THC})$. Nakon toga uslijedilo je otkriće endogenih liganda kao i receptora $\mathrm{CB}_{1}$ i $\mathrm{CB}_{2}$ na koji se vežu endokanabinoidi.

Endokanabinoidi u širem smislu djeluju kao neuromodulatori i imunomodulatori. Uključeni su u različite fiziološke procese kao što su: pojava boli, kognitivni procesi, formiranje pamćenja i neuroplastičnost, motoričke aktivnosti, endokrini procesi, regulacija apetita, kontrola i broj otkucaja srca, mučnina i povraćanje, intraokularni pritisak, inflamatorni i imunološki procesi (prepoznavanje antigena).

Ključne riječi: Endokanabinoidi, anandamid, kanabinoidni receptori. 